\title{
AN ANTHOLOGY OF THE DISTINGUISHED ACHIEVEMENTS IN SCIENCE AND TECHNIQUE. PART 49: AIRCRAFT DESIGNER OLEG ANTONOV AND HIS ACCOMPLISHMENTS IN AIRPLANE DESIGN
}

Purpose. Preparation of short scientifically-historical essay about one of founders of domestic aircraft design, prominent Ukrainian aircraft designer O.K. Antonov. Methodology. Known scientific methods of collection, analysis and analytical treatment of scientific and technical information, touching becoming and development of Soviet aviation and resulted in scientific monographs, journals and internet reports. Results. A short scientifically-historical essay is resulted about the prominent Ukrainian aircraft designer Oleg Konstantinovich Antonov, becoming one of founders of Soviet military cargo and civil aviation. Basic scientific and technical achievements of the glorified aircraft designer O.K. Antonov are indicated and team of headed them in the period of 1952-1984 of legendary Design Bureau 473 (Kyiv) in area of aircraft design, bringing a domestic aviation around to world heights. Basic tactical and technical descriptions are described created under his scientific and technical guidance of such types of passenger airplanes known in the world as An-2, An-10 and An-24, and also troop-carriers of type An-12, An-22 "Antaeus", An-26, An-30, An-32, An-72 and An-124 «Ruslan». Short information is resulted about tactical and technical descriptions of the largest in the world of heavy distant turbo-jet military cargo airplane type An-225 «Mriya», created in 1980-th years in Design Bureau named after O.K. Antonov. It is marked that under scientific and technical guidance of aircraft designer O.K. Antonov in the former USSR about 100 types of aircrafts of the military and civil aircrafts were developed and created. It is pointed out that Doctor of Technical Sciences, Academician of the Academy if Sciences the Ukrainian SSR and of the Academy of Sciences the USSR became a founder acknowledged in the world of Ukrainian aviation scientific school. Information, touching common to all mankind qualities of this great aircraft designer, is resulted, and also handed O.K. Antonov for merits before Homeland of governmental rewards, bonuses and other insignia, underlining his prominent contribution to development of domestic aircraft construction. Originality. Certain systematization is executed known from scientific journals and other mass of scientific and technical materials media, touching becoming and development in the period of 20-21-th centuries of Soviet aviation and ponderable scientific and technical contribution to the military and civil aircraft design of the prominent Ukrainian aircraft designer O.K. Antonov. Practical value. Scientific popularization and deepening for the students of higher school, engineering, technical and scientific workers of scientific and technical knowledge in area of history of becoming and development of Soviet aircraft design, extending their scientific and technical range of interests and further development of scientific and technical progress in society. References 13, figures 17.

Key words: aviation technique, prominent Ukrainian aircraft designer Oleg Antonov, basic achievements in airplane design, scientifically-historical essay.

Наведено короткий науково-історичний нарис про видатного украйнського авіаконструктора Олега Костянтиновичі Антонова, що став одним з основоположнників вітчизняного літакобудування. Описані основні науково-технічні досягнення О.К. Антонова в галузі літакобудування, щцо принесли славу радянської військової $і$ цивільної авіації $і$ нашій Вітчизні. Показано, цо авіаконструктор О.К. Антонов заснував в м. Києві відому в світі украйнську авіаційну наукову школу. Під керівництвом авіаконструктора О.К. Антонова в його ОКБ було розроблено близько 100 типів літальних апаратів військового і цивільного призначення. Бібл. 13, рис. 17.

Ключові слова: авіаційна техніка, видатний український авіаконструктор Олег Антонов, основні досягнення в літакобудуванні, науково-історичний нарис.

Приведен краткий научно-исторический очерк о выдающемся украинском авиаконструкторе Олеге Константиновиче Антонове, ставщем одним из основоположников отечественного самолетостроения. Описаны основные научно-технические достиясения О.К. Антонова в области самолетостроения, принесиие славу советской военной и гражданской авиации и нашему Отечеству. Показано, что авиаконструктор О.К. Антонов основал в 2. Киеве известную в мире украинскую авиационную научную школу. Под руководством авиаконструктора О.К. Антонова в его ОКБ было разработано около 100 типов летательных аппаратов военного и гражданского назначения. Библ. 13, рис. 17.

Ключевые слова: авиационная техника, выдающийся украинский авиаконструктор Олег Антонов, основные достижения в самолетостроении, научно-исторический очерк.

Introduction. As is well known, a modern aircraft, including an airplane, is a complex technical object containing various devices and systems based on the operation of which of electricity directly or indirectly. For operation of on-board equipment of any aircraft, constant and alternating electrical voltage generated by various powerful electrical sources (for example, batteries, motor converters, fuel cells, solar power plants, small nuclear generators, etc.) is necessary. Therefore, the world aircraft industry is inextricably linked with electrical engineering, penetrating all modern technology. Considering the development of the aircraft industry, we simultaneously consider the development of the electrical industry in relation to the aircrafts. The history of the progressive development of technology on our planet is made by people. This is especially evident in the creative work of outstanding scientists in a particular area of scientific and technical knowledge. One of such outstanding personalities in the field of domestic aircraft design was the Ukrainian aircraft designer, Academician of the Academy of Sciences of the Ukrainian SSR (since 1968) 
and the Academy of Sciences of the USSR (since 1981) Oleg Konstantinovich Antonov (Fig. 1) [1].

The goal of the paper is the preparation of a brief scientific and historical essay about one of the founders of the domestic aircraft industry, an outstanding Ukrainian aircraft designer O.K. Antonov.

1. The beginning of the life and career of O.K. Antonov. He was born on February 7, 1906 in the village of Troitsa, Moscow Province of the Russian Empire, in the Russian noble family of Anna Efimovna (nee Bikoryukina) and Konstantin Konstantinovich Antonov [1]. Oleg's father was a civil engineer. In 1912 his family moved to the city of Saratov, located on the banks of the great river Volga. In the period 1915-1922 he first studied at the Saratov Real School (he graduated from two classes), and then in high school (now it is school No. 23 [1]). From a young age O.K. Antonov was interested in aircraft engineering and was enthusiastically engaged in the aviation amateur school club. In 1924, while studying at the University of Saratov at the Railway Department, he built his first glider, the «Dove»[1]. In 1925, Oleg Antonov entered the Engineering Department of the Leningrad Polytechnic Institute (LPI), which he graduated in 1930 and became a mechanical engineer.

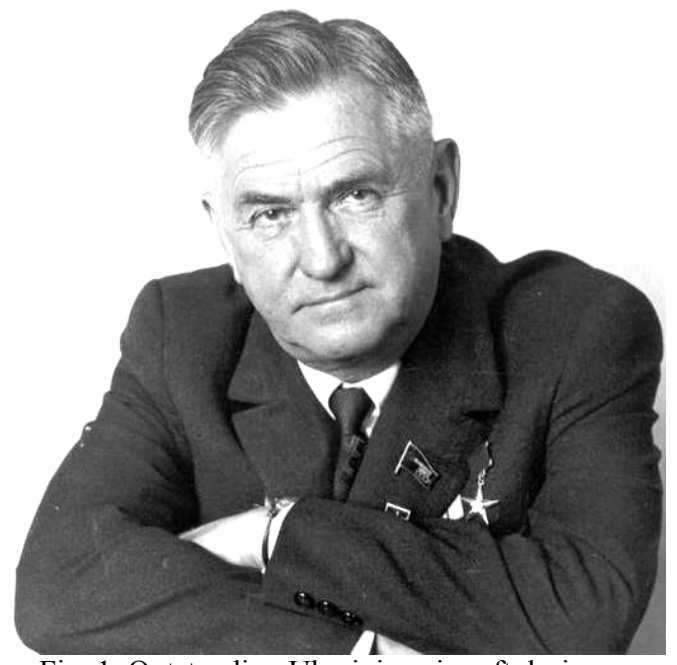

Fig. 1. Outstanding Ukrainian aircraft designer,

Hero of Labor, Doctor of Technical Sciences, Academician of the Academy of Sciences of the Ukrainian SSR and the Academy of Sciences of the USSR

Oleg Konstantinovich Antonov (07.02.1906-04.04.1984) [1]

In 1933, O.K. Antonov, working as a chief designer at the Osoaviakhim glider bureau (Leningrad), was appointed chief designer at the design bureau of the first glider plant in the former USSR built in Moscow (Tushino district) [2]. The decision-makers of the country ordered to this design bureau to develop new light-wing machines, which would be massively manufactured at this plant. For five years of work in the city of Moscow, O.K. Antonov designed more than 20 types of gliders produced at the plant in Moscow Region [3]. In 1938, this plant was closed and O.K. Antonov was out of work. In this situation, he had to turn to his comrade on the All-Union gliders rally in the Crimea (Koktebel), the Head of the aircraft-building experimental Design Bureau Alexander
Sergeyevich Yakovlev, who later became an outstanding Russian aircraft designer and three times Hero of Labor [2]. So O.K. Antonov became only the lead engineer (after the position of chief designer of the glider design bureau occupied by him in Moscow) in the Design Bureau of A.S. Yakovlev. In the spring of 1940, O.K. Antonov was again appointed chief designer of a small design bureau at an aircraft plant in Leningrad, and in the first half of 1941 he was transferred to the aircraft plant No. 465 (Kaunas, Lithuanian SSR) in his previous position. And here he was when the Great Patriotic War (WWII) began. Upon his arrival in Moscow, the Commissariat of the Aviation Industry of the USSR entrusted him with the combat mission - the urgent creation of a landing glider [2]. And here the new order was to evacuate beyond the Urals in Tyumen city and create such a glider there. So in military conditions for a couple of months, O.K. Antonov and his colleagues developed an A-7 type airborne glider, which greatly assisted the partisan movement during the Second World War. Therefore, it is no coincidence that O.K. Antonov in 1944 was awarded the medal «Partisan of the Patriotic War». In February 1943 he was again transferred to the Design Bureau of Major General A.S. Yakovlev, where he becomes his deputy and is engaged in the modernization of the famous military fighter aircrafts during the Second World War, ranging from the Yak-3 and ending with Yak-9 [3].

2. The main achievements of the aircraft designer O.K. Antonov in aircraft construction. In the autumn of 1945, O.K. Antonov was offered to head the Siberian branch of the Design Bureau of A.S. Yakovlev at the aircraft plant named after V.P. Chkalov (Novosibirsk city). He agreed without hesitation. He had to independently create not military aircraft, but agricultural and passenger planes. By the Resolution of the Council of Ministers of the USSR of May 31, 1946, this branch was transformed into a new aircraft-building Design Bureau No. 153 and O.K. Antonov became his chief designer [2]. The first-born aircraft of this design bureau took off on August 31, 1947. It turned out to be the multi-purpose aircraft of the An-2 type known in the aviation world, affectionately named by the people as «Annushka» (Fig. 2 ). Note that this airplane was the only aircraft in the world that has been mass-produced for over 50 years [3]. He won the fame of an exceptionally reliable flying machine. In 1952, O.K. Antonov and his associates for the creation of this aircraft were awarded the Stalin (State) Prize of the second degree. In the same 1952, O.K. Antonov and his leading specialists moved to the city of Kyiv and began to organize a new Design Bureau No. 473 from scratch [2]. In this connection, it is worth citing the words of O.K. Antonov [2]: «... The collective is not created by orders, although they are needed. It is not created only by picking and rearranging people. The team does not unite by the building in which it works. The main thing without which the team can not exist, it is the unity of purpose. Creating a friendly, workable team is a special work, work of a higher order». 


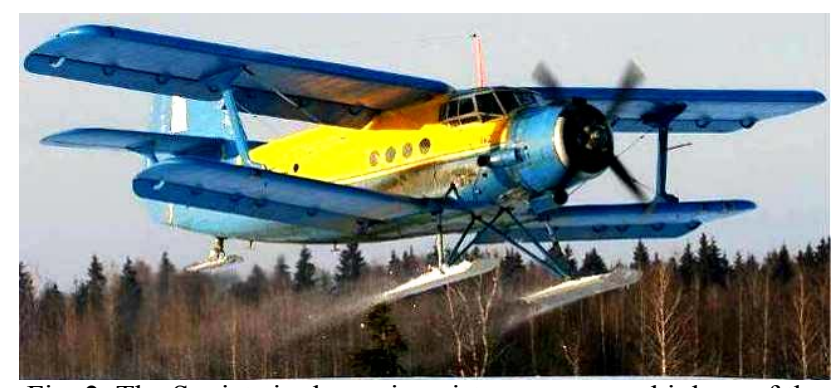

Fig. 2. The Soviet single-engine piston passenger biplane of the An-2 type «Annushka» (known to many as the «Kukuruznik») developed by the aircraft designer O.K. Antonov and his Design Bureau No. 153 (1947, Novosibirsk, USSR) [2]

The first contribution of the new design bureau to the development of the Soviet military transport aviation was a twin-engine gas turbine aircraft of the An-8 type (Fig. 3) [2].

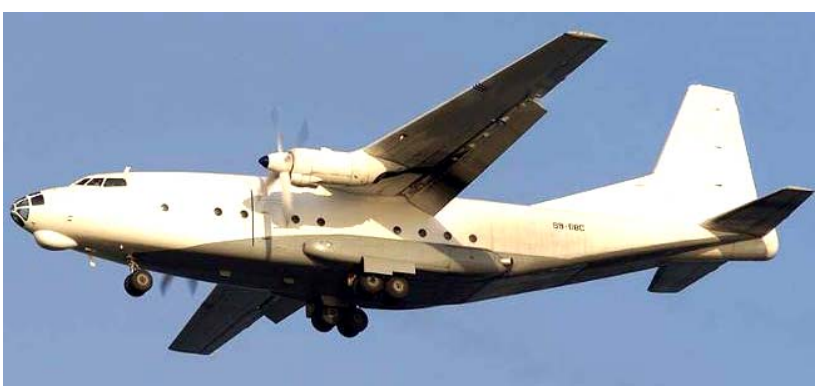

Fig. 3. Soviet twin-engine gas turbine military transport aircraft of the An- 8 type developed by the aircraft designer

O.K. Antonov and his Design Bureau No. 473 (the lead designer of the project is A.Ya. Belolipetsky, 1958, Kyiv, Ukrainian SSR) [2]

In accordance with the Resolution of the Council of Ministers of the USSR of November 30, 1955, the Kyiv Design Bureau was entrusted with the creation of the country's first four-engine turboprop passenger aircraft for medium-range air lines and relatively short landing lanes. It turned out to be the An-10 type aircraft (Fig. 4), launched into mass production in 1957 [2].

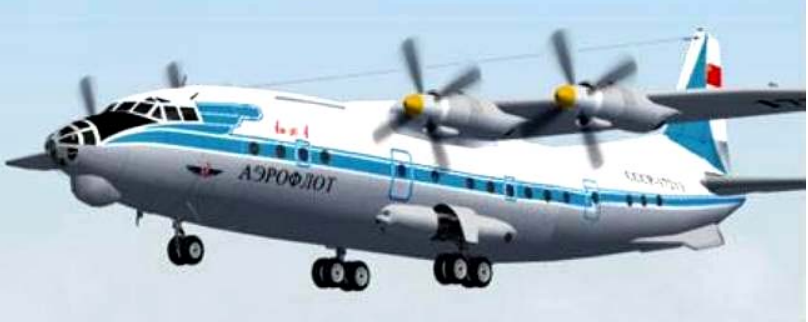

Fig. 4. The first Soviet medium-haul four-engine turboprop passenger aircraft of the An-10 type developed by the Chief Aircraft Designer O.K. Antonov and his Design Bureau No. 473 (1957, Kyiv, Ukrainian SSR) [2]

An-10 aircraft carried more than one million passengers throughout the vast Soviet country $[2,3]$.

New government order for O.K. Antonov and his design bureau became the development of a four-engine turboprop military transport aircraft of the An-12 type (Fig. 5) [2]. The capacity of this aircraft was increased to 20 tons. He could fly to the Arctic at the drifting stations of the USSR «North Pole» and to the Antarctic at the station «Mirny» [2, 3].

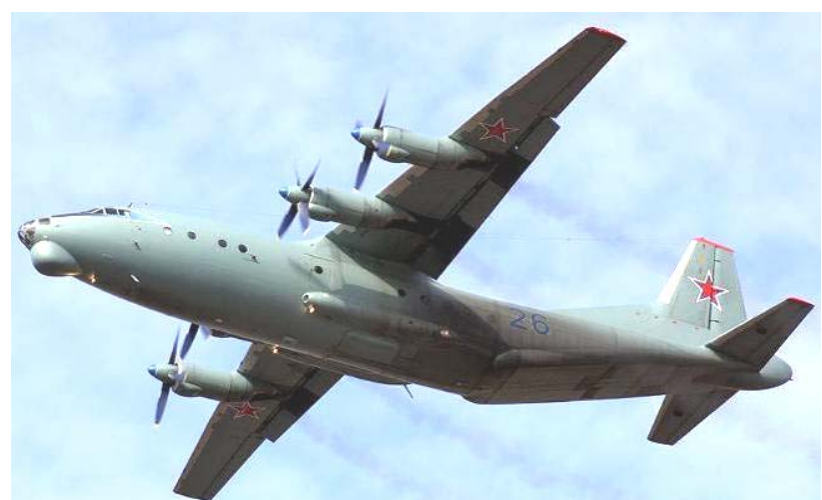

Fig. 5. Soviet four-engine turboprop military transport aircraft of the An-12 type developed by the Chief Aircraft Designer O.K. Antonov and his Design Bureau No. 473 (1959, Kyiv, Ukrainian SSR) [2]

Since 1959 this aircraft with a take-off mass of 61 tons has been supplied to the country's Air Forces. In terms of its tactical and technical characteristics, it significantly exceeded foreign analogues [2]. For the creation of the An-12 aircraft, members of the group of authors from the Kyiv Design Bureau in 1962 were awarded the USSR Lenin Prize. After the creation of the An-10 and An-12 aircrafts, the Design Bureau No. 473 led by the talented Ukrainian aircraft designer O.K. Antonov took a deserved place among the leading aircraft-building firms of the Soviet country [2, 3].

In 1960, the twin-engine turboprop aircraft of the An-24 type (Fig. 6) developed in the Kyiv Design Bureau under the guidance of O.K. Antonov "came out» onto the passenger lines of our country, and later of many foreign countries [2]. The serial production of the An-24 type aircraft continued until 1979. During this time, about 1,200 machines were manufactured with 1000 of them produced at the «Aviant» Aviation Plant in Kyiv [2]. It served 450 air lines in the USSR. This flying machine was successfully exported to 25 countries of the planet $[2,3]$.

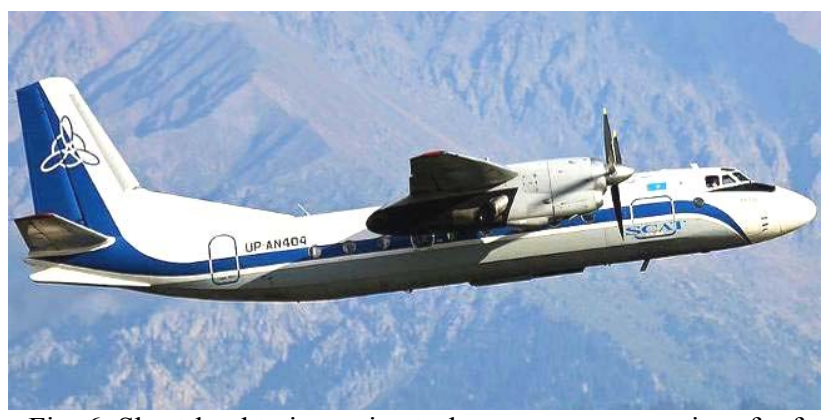

Fig. 6. Short-haul twin-engine turboprop passenger aircraft of the An-24 type developed by aircraft designer O.K. Antonov (1960, Kyiv, Ukrainian SSR) [2]

On the basis of the design of the An-24 passenger aircraft with the wide use of glued-welded joints of many elements of this aircraft in the future, the Kiev Design Bureau created An-26 military transport aircraft (Fig. 7) and An-30 aerial photography aircraft (Fig 8) [2,3]. 


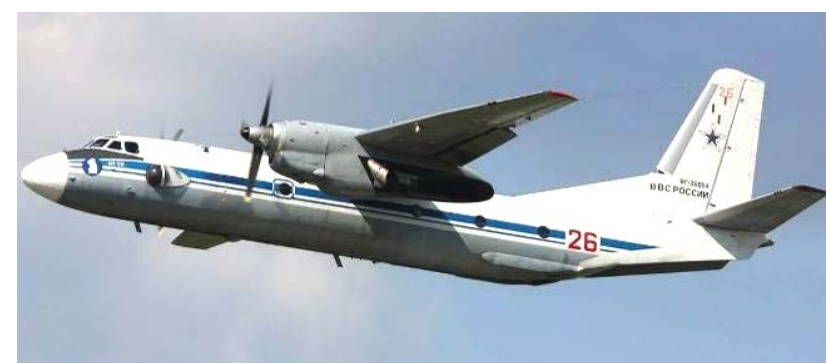

Fig. 7. Soviet twin-engine turboprop military transport aircraft of the An-26 type developed by aircraft designer O.K. Antonov (1962, Kyiv, Ukrainian SSR) [2]

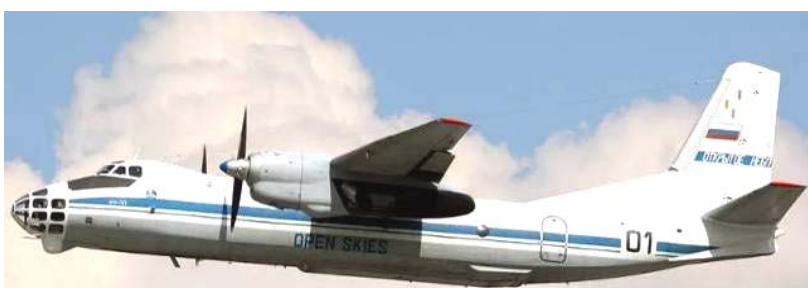

Fig. 8. Soviet twin-engine turboprop aerial photography aircraft of the An-30 type developed by aircraft designer O.K. Antonov and his Design Bureau No. 473 (1963, Kyiv, Ukrainian SSR) [2]

The next flying «brainchild» of the Design Bureau's team, headed by O.K. Antonov, became the world's first wide-body military transport aircraft type An-22 «Antaeus» (Fig. 9) [2]. The creation of this domestic airplane marked the onset of a new stage in the global aircraft industry. In terms of its tactical and technical characteristics, it surpassed everything that was created in world aviation before it.

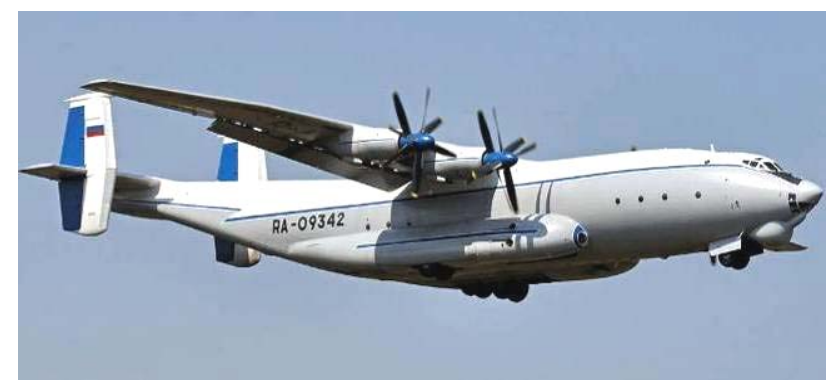

Fig. 9. The first Soviet military transport four-engine turboprop giant aircraft of the An-22 «Antaeus» type (60 tons payload; it set 12 world records) developed by General Designer

O.K. Antonov and his Kyiv Design Bureau No. 473 (1965, Kyiv, Ukrainian SSR) [2]

The creation of the An-22 «Antaeus» type aircraft required a comprehensive solution of many scientific design and technological problems, as well as a huge amount of experimental work [2]. At the 26th International Aviation and Space Salon at Le Bourget (1965, Le Bourget, Paris), this domestic aircraft was in the center of the general attention of viewers and specialists and produced a real scientific and technical sensation. The English newspaper The Times wrote on this occasion [2]: «... Thanks to this plane, the Soviet Union was ahead of all other countries in the aircraft industry». Delivery of large cargoes (for example, gas turbine stations, rotor excavators and trucks) to the Far North of the USSR with the help of the An-22 «Antaeus» type aircrafts confirmed that thanks to this unique aircraft transport aviation made a new progressive step forward.

In the 1960s, the Kyiv Design Bureau under the leadership of its General Designer O.K. Antonov (this high rank was conferred on him in 1962) continued work on the modernization of the An-26 aircraft and, as a result, developed a new design of the domestic highaltitude turboprop record airplane of the An-32 type (Fig. 10).

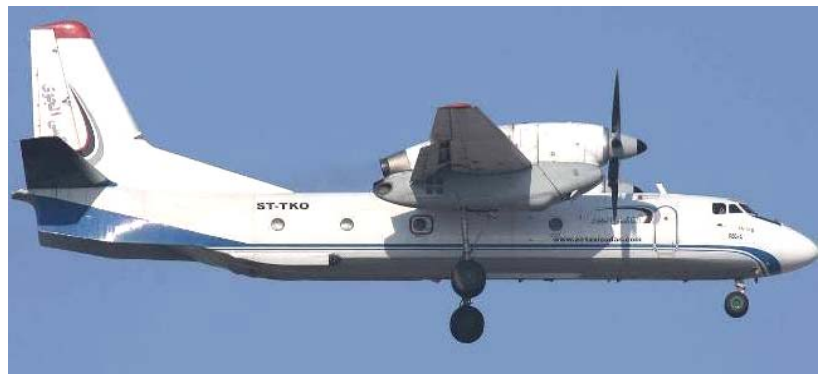

Fig. 10. Lightweight twin-engine turboprop transport aircraft of the An-32 type developed by General Designer O.K. Antonov (1964, Kyiv, Ukrainian SSR) [2]

In 1976, the next Resolution of the Council of Ministers of the USSR on the development and creation instead of the An-26 type aircraft by the Kyiv Design Bureau of a new twin-engine turbojet military transport aircraft, necessary for the uninhabited regions of the country with no concrete airfields, was adopted [2]. On August 31, 1977, such an aircraft, called the An-72 (Fig. 11), successfully completed its first flight. In 1978, the An-72 was launched into pilot production at the Kyiv aircraft plant, and in 1985 into serial production at the Kharkiv aircraft plant [3].

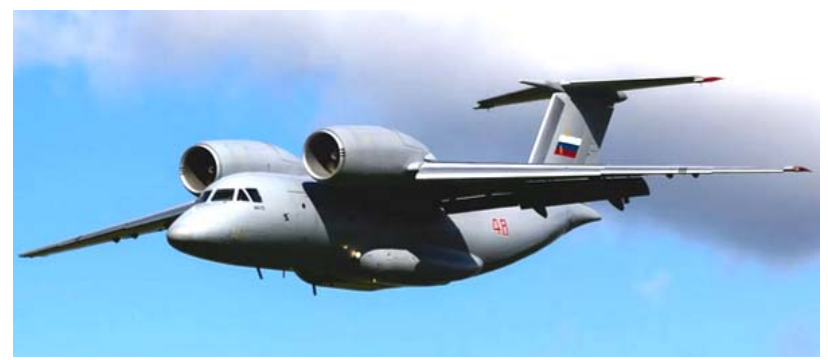

Fig. 11. Soviet twin-engine turbojet military transport aircraft of the An-72 type (affectionately called «Cheburashka» by pilots and aviation specialists) developed by General Designer

O.K. Antonov and his legendary Design Bureau (1978, Kyiv, Ukrainian SSR) [2]

The An-72 type aircraft also had a civil modification. The power plant of this aircraft included two powerful turbojet engines of the Д-36 type mounted above the wing for use during its flight of the Coanda effect - the growth of lift due to the «sticking» of the exhaust jet to the wing [2]. The airframe design of the An72 type aircraft, in which composite materials were widely used [4], was made all-metal. The main tactical and technical characteristics of the An-72 type aircraft 
[5]: maximum flight speed $705 \mathrm{~km} / \mathrm{h}$ (its cruising speed $550 \mathrm{~km} / \mathrm{h}$ ); flight range $2700 \mathrm{~km}$; ceiling (lifting height) $10100 \mathrm{~m}$; maximum take-off weight 32 tons; empty aircraft mass 19.5 tons; hull length $28 \mathrm{~m}$; runway length $800 \mathrm{~m}$, and the run $450 \mathrm{~m}$. Note that over time, a modification of this aircraft appeared in the USSR, called An-74 [2, 5].

Under the scientific and technical guidance of the Ukrainian aircraft designer O.K. Antonov the extremely difficult task of developing and building in the USSR a new heavy long-range military transport aircraft of the An-124 «Ruslan» type (Fig. 12) successfully was solved Fig. 12) $[2,6]$. For this, General Designer O.K. Antonov went on very bold technical solutions for that time. In particular, the swept wing of a supercritical profile was used for the first time in the world on a plane of this class [6].

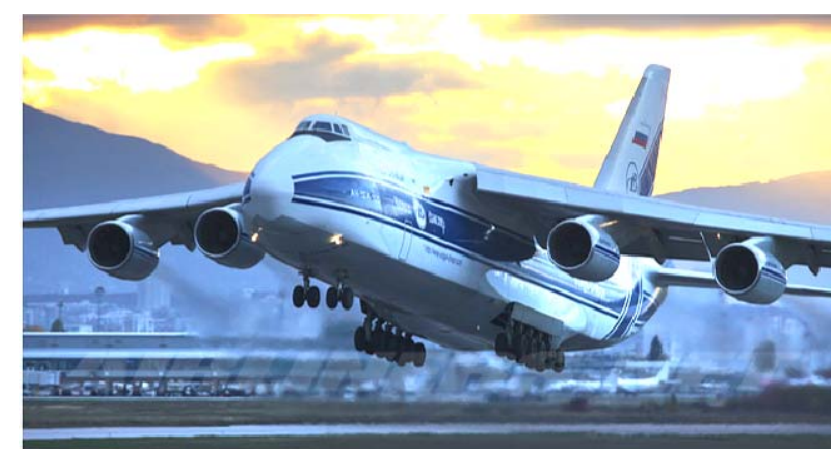

Fig. 12. Soviet heavy long-range four-engine turbojet military transport giant of the An-124 «Ruslan» type - a «swan song» by the General Designer O.K. Antonov (1982, Kyiv, Ukrainian SSR) [2]

One of the technological methods that made it possible to achieve a high weight index for the An-124 «Ruslan» type aircraft was the wide use of composite materials in it $[4,6]$. Today, this aircraft is the largest mass-produced transport aircraft. We point out that the An-124 «Ruslan» military transport aircraft is currently used in cooperation with NATO countries in the transport of large-sized military cargoes (Fig. 13) [2].

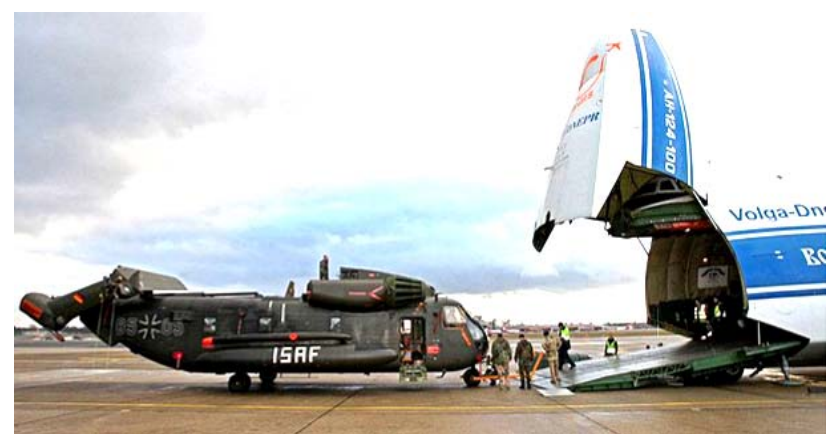

Fig. 13. Loading a German military helicopter into the An-124 «Ruslan» military transport aircraft of the Volga-Dnepr international air transport company [2]

We emphasize the fact that for any design bureau in the world there are special projects, in the work on which its specialists reached the «top» of their professional skills. For the Kyiv Design Bureau, under the leadership of twice Academician (of the Republican and Union
Academies of Sciences) O.K. Antonov such a project was the aircraft of the type An-124 «Ruslan». Describing the features of this aircraft, which set 30 world records (as of 2006, there were 483 world records at the O.K. Antonov Design Bureau, 378 of which have not been beaten yet), experts often use the words «unique», «not having analogues in world aviation» and others [2, 6]. Kiev aircraft manufacturers have developed and created a lot of excellent airplanes. But even in this domestic aviation series, the An-124 «Ruslan» type of aircraft is a monumental technical object [6]. This aircraft was the last one created under the direct scientific and technical guidance of the great Ukrainian aircraft designer O.K. Antonov.

Let us give the basic tactical and technical characteristics of the An-124 «Ruslan» type aircraft [6]: wingspan $73.3 \mathrm{~m}$; body length $69.1 \mathrm{~m}$; height $20.8 \mathrm{~m}$; empty aircraft mass 173 tons; maximum take-off weight 405 tons; normal take-off weight 392 tons; power plant is four turbofan engines Д-18Т; maximum flight speed 865 $\mathrm{km} / \mathrm{h}$; cruising flight speed $(750-800) \mathrm{km} / \mathrm{h}$; flight range $4500 \mathrm{~km}$; ceiling (lifting height) $9500 \mathrm{~m}$; useful flight load (120-150) t; crew is 6 people.

Orienting the team of the Kyiv Design Bureau to the solution of new problems, O.K. Antonov in one of his last speeches said [2]: «... Then you can only go in a revolutionary way, mastering new ideas. And, as you know, there are no limits to the new technology». After the death of General Designer O.K. Antonov his aviation plans embodied in the «life» of his talented followers.

In December 1988, at the Design Bureau named after O.K. Antonov, under the leadership of General Designer Peter Vasilyevich Balabuev, a new Soviet heavy long-range military transport turbojet aircraft of the An225 «Mriya» type was created (Fig. 14) [2, 7].

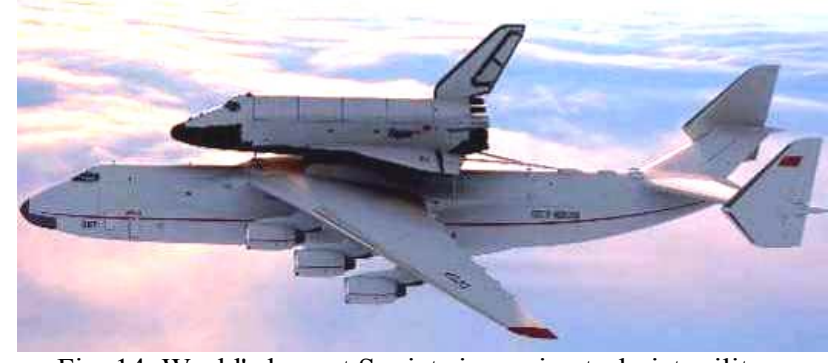

Fig. 14. World's largest Soviet six-engine turbojet military transport giant of the An-225 «Mriya» type developed by the Design Bureau named after O.K. Antonov (1989, the photo was taken during the transportation of the «Buran» space shuttle by this plane) [2]

The An-225 «Mriya» type aircraft of extra-large carrying capacity, created on the basis of the design of the An-124 «Ruslan» type aircraft, is the largest aircraft in the world. It is designed to transport bulky goods weighing up to 250 tons inside the fuselage or on an external suspension to anywhere in the world. This aircraft can also be used as a launch complex for military space forces or launch vehicles of a new generation [2, 7]. Initially, it was created to transport a number of components of super-power launch vehicles of the «Energia» type and the Soviet «Buran» shuttle shuttle spacecraft from the 
manufacturers of the USSR to the southern Baikonur cosmodrome. Its first test flight took place on December 21, 1988, which was a huge victory for Soviet aviation. On March 22, 1989, the An-225 «Mriya» made its flight with a payload of 156.3 tons on board. During this flight of the An-225 «Mriya» type aircraft, 109 world aviation records were set at once.

Let us indicate the main tactical and technical characteristics of the An-225 «Mriya» type aircraft [7]: wingspan $88.4 \mathrm{~m}$; body length $84 \mathrm{~m}$; height $18.2 \mathrm{~m}$; empty aircraft mass 250 tons; maximum take-off weight 600 tons; fuel weight 300 tons; power plant S six turbofan engines Д -18Т; cruising flight speed $850 \mathrm{~km} / \mathrm{h}$; practical flight range $15600 \mathrm{~km}$; practical ceiling $11000 \mathrm{~m}$; useful flight load up to 250 tons; crew is 6 people.

It should be noted that in 2001, the relevant aviation services of Ukraine were issued certificates for the An225 «Mriya» aircraft of its compliance with the standards of civil aviation aircraft. Currently, the only flying specimen of the An-225 «Mriya» type aircraft performs commercial cargo transportation as a part of the air transport division of the Sate Enterprise «Antonov» Ukrainian «Antonov Airlines» Company [7]. From May 10 to 15,2016 , the An-225 «Mriya» type airplane made a flight along the Ukraine-Australia route, making four intermediate landings along the way with refueling [7]. Here, the full range of the flight with bulky cargo on board (generator of the «Brush SEM» Company weighing 117 tons) was 15.5 thousand $\mathrm{km}$. Today, the An-225 «Mriya» is the owner of 250 world aviation records. The aircraft of the type An-225 «Mriya» is listed in the Guinness Book of Records [7].

In conclusion of this section, we point out that the Scientific-\&-Research Planning-\&-Design Institute «Molniya» of the Kharkov Polytechnic Institute (KhPI), now called the National Technical University (NTU) $\mathrm{KhPI}$, has a certain relation to the development and creation at the Design Bureau, headed by O.K. Antonov, a number of transport aircraft. Here, the participation of specialists from the KhPI consisted in the joint solution of important tasks to ensure electromagnetic compatibility (EMC) and lightning protection of electronic equipment of such aircrafts (in particular, the An-124 «Ruslan» type aircraft) with designers of the Design Bureau. For the performance of these works, a number of employees of the Scientific-\&-Research Planning-\&-Design Institute «Molniya» of the NTU «KhPI» twice (in 2004 and 2014) were members of authors' teams whose were awarded the high title of Laureate of the State Prize of Ukraine in the field of science and technology. At present, such scientific and technical cooperation on the basis of contractual work between the Scientific-\&-Research Planning-\&-Design Institute «Molniya» of the NTU «KhPI» and the «Antonov» State Enterprise continues successfully. Its main tasks are the issues of providing EMC and durability of onboard devices and structural elements (for example, fuel tanks) of «Antonov» aircraft to the damaging effect of such a natural source of powerful pulsed electromagnetic interference (fields, currents and voltages) as linear lightning. The Scientific-\&-Research Planning-\&-Design Institute «Molniya» of the NTU «KPI» to simulate the effects of lightning on the aircrafts has the necessary high-voltage high-current electrophysical equipment of its own manufacture [8].

3. The universal human qualities of the aircraft designer O.K. Antonov. What kind of person in the life people remembered this outstanding Ukrainian aircraft designer? Externally, Oleg Konstantinovich looked much younger than his years (Fig. 15). He remained young in spirit, too. He is remembered by a man of athletic build, well dressed, elegant, emphatically intelligent and helpful in communication. He was distinguished by a rare spirituality. Perhaps this helped him to become not just famous, but the legendary aircraft designer [9]. Its distinguishing feature as an aircraft designer is that he did not create any combat «strike» aircraft - attack aircraft or bomber (of course, for this, in the former USSR there were other special design bureaus). All of his planes were produced as both passenger and transport. In each of his flying machine, O.K. Antonov provided an opportunity for its peaceful application. He impressed everyone who came across him with his highest inner culture, extraordinary erudition and range of his interests and hobbies [10]. It would be naive to assume that the creation and implementation into practice of the aircrafts, developed under the guidance of O.K. Antonov, as well as the solution of many problems in a large team of the Kyiv Design Bureau, passed without various contradictions and conflicts.

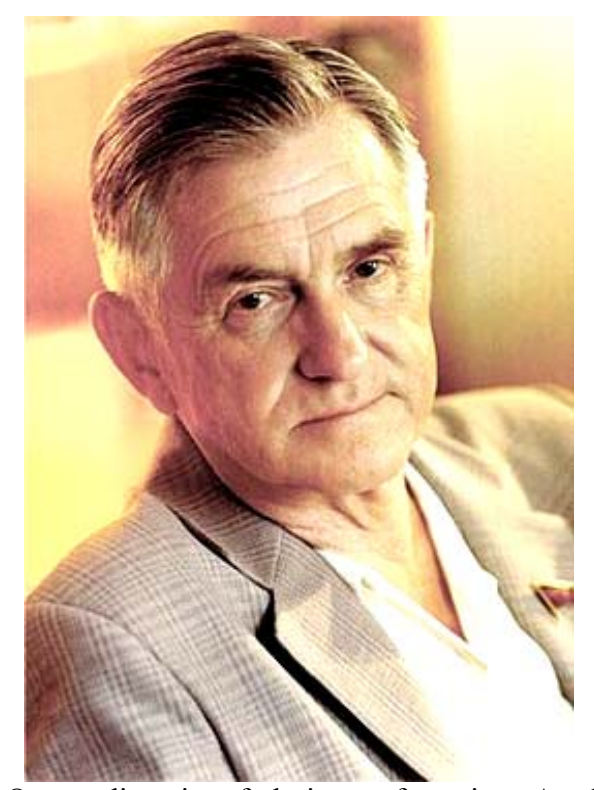

Fig. 15. Outstanding aircraft designer of our time, Academician

O.K. Antonov in a quiet homely atmosphere in the period of successful conquest of his life and creative «heights»

(1970s, Kyiv, Ukrainian SSR) [1]

A characteristic feature of the Soviet era in which O.K. Antonov worked, there was bureaucracy. Often the only way out of the situation at the design bureau and outside it was the struggle, which took away the aircraft designer infinitely many strength and health, undermined by a serious illness (tuberculosis) in the prewar period [2]. Oleg Konstantinovich married three times. In 1936, Lydia Sergeevna Kochetkova gave birth to his son Rolland. Elizaveta Avetovna Shakhatuni (an aircraft designer who 
has worked with him for several decades) gave birth to his daughter Anna. And the third young wife Elvira Pavlovna gave birth to his son Andrei and the daughter Elena. The most surprising thing here is that the aircraft designer with all his spouses until his death (he died of a stroke and was buried in the Baikovo cemetery, Kyiv) communicated cordially and in a friendly way [8]. By the way, after the third marriage of the General Designer of the Design Bureau, his superiors scolded him for «old-time pranks»» (there was no trial, but the corresponding «treatment» was) [2]. We can only mentally imagine what kind of nerves for Oleg Konstantinovich all this «cost» and what he had to «pay» for his production and family victories.

At the work O.K. Antonov has always been strongly opposed to administrative-command methods of management. He almost never ordered. In his inherent intelligent form, he advised the employee or asked him about the execution of a particular task. Having become a world-famous aircraft designer, Oleg Konstantinovich amazed his subordinates with his very easy accessibility [9]. He had an amazing ability to recognize talented people. In all possible ways and forces he supported their undertakings and aspirations. He tried to invite them to work with him. This support for gifted people O.K. Antonov also transferred to students, having been successfully engaged in teaching since 1977 (he had the academic title of Professor) at the Kharkiv Aviation Institute (KhAI) named after N.E. Zhukovsky (in this high school he for many years headed the Department for Aircraft Design) and preparing for Ukraine's aircraft industry a new worthy shift $[2,9]$. Under his «wing» there was the formation of many aircraft designers in Ukraine and abroad. At the Kyiv Design Bureau headed by Academician O.K. Antonov the Ukrainian aviation Scientific school recognized in the world has been established $[9,10]$.

From the memories of E.A. Shakhatuni (a close associate of O.K. Antonov and the LAureate of the Lenin Prize of the USSR) [2]: «... The main thing that characterizes Oleg Konstantinovich is his unconditional talent, exceptional love for his work, and, of course, intelligence. These qualities in the first place determined his relationship with the team. Everyone who came to work with Oleg Konstantinovich was immediately infected with his obsession. He was able to arrange people in such a way so as not to push them in their work. Employees themselves became carriers of his aspirations and his ideas».

In the capital of Ukraine, city of Kyiv, on May 31, 2012, on the territory of the legendary Design Bureau No. 473 in honor of its former scientific and technical leader, an outstanding Ukrainian aircraft designer, Academician O.K. Antonov bronze monument was opened (Fig. 16) [11].

In the first capital of Ukraine, city of Kharkiv, on May 26, 2012, on one of the walls of the main educational building of the KhAI named after N.E. Zhukovsky, currently called the National Aerospace University named after N.E. Zhukovsky, in honor of his teacher, Professor, Academician O.K. Antonov bronze plaque was opened (Fig. 17) [12].

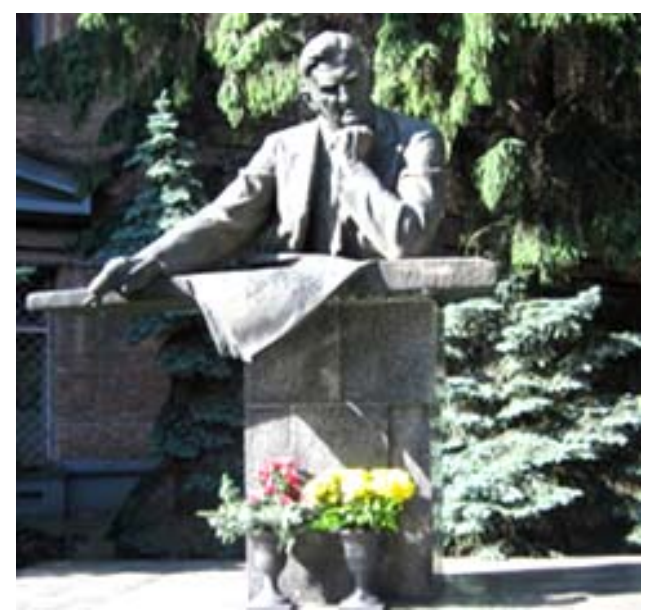

Fig. 16. Bronze monument to the Head of the legendary Design Bureau No. 473 Oleg Konstantinovich Antonov installed in the territory of the Aviation Scientific-Technical

Complex named after O.K. Antonov (sculptor A. Shatalov; Kyiv, Academic Tupolev Str. 3, Ukraine) [11]

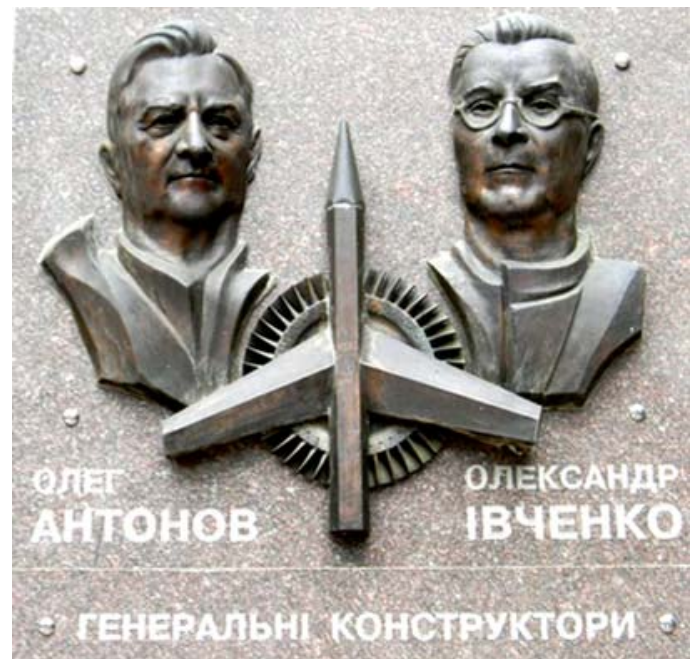

Fig. 17. A plaque in honor of the General Designer of the legendary Design Bureau No. 473 O.K. Antonov mounted on the wall of the educational building of the KhAI named after N.E. Zhukovsky (now National Aerospace University named after N.E. Zhukovsky, Kharkiv, Chkalov Str. 17, Ukraine) [12]

4. Awards and honors of O.K. Antonov. For outstanding merits of Oleg Konstantinovich Antonov in the field of domestic aircraft design, since November 19, 1984, the Kyiv Design Bureau was called the Design Bureau named after O.K. Antonov whose historical successor is the «Antonov» State Enterprise which is now apart of the State Concern «Ukroboronprom» [13].

For great success in the design of new aviation technology and in connection with the 60th anniversary of the birth, O.K. Antonov in 1966 was awarded the title of Hero of Labor 1966 and he was awarded the «Hammer and Sickle» gold medal. He became a holder of six orders (1944, 1945, 1957, 1966, 1971, 1975) of the Soviet country. For valiant work during the Second World War he was awarded a number of combat medals. He became the Laureate of the State (1952) and Lenin (1962) Prizes of the USSR, as well as the Honored Worker of Science and Technology of the Ukrainian SSR. In 1976, the creative work of an outstanding aircraft designer was 
awarded the State Prize of the country in the field of science and technology for the creation and introduction of the An-24 passenger turboprop aircraft. He was awarded the A.N. Tupolev Gold Medal of the Academy of Sciences of the USSR (1979). He became an honorary citizen of the city of Saratov (1981). The streets in Kyiv, Saratov, Vinnitsa and Ulan-Ude as well as avenue in Ulyanovsk were named after him. In 2006, postage stamps of Ukraine and Russia dedicated to O.K. Antonov and the most famous aircrafts of his design were issued.

Conclusions. Outstanding Ukrainian aircraft designer, Academician of the Academy of Sciences of the Ukrainian SSR and the Academy of Sciences of the USSR Oleg Konstantinovich Antonov who was in the period 1952-1984 an authoritative scientific and technical leader of the world famous legendary Soviet aircraft Design Bureau No. 473, Kyiv made an enormous personal contribution to the development of domestic military transport and civil aviation. Under his direct design guidance, about 100 types of aircrafts were developed and built including the fascinating hobby of his youth - lightwing gliders. The unique four-engine turbojet military transport giant of type An-124 «Ruslan» possessing a payload up to 150 tons and performing commercial flights around the globe and today reliably transporting heavy expensive large-sized equipment to long-distance distances is a triumph of his aviation talent. At present, his aviation work in Ukraine is continued by the creatively inspired colleagues and followers of this talented scientist and designer.

\section{REFERENCES}

1. Available

https://en.wikipedia.org/wiki/Oleg Antonov (aircraft designer) (accessed 15 June 2017).

2. Available at: http://nk.org.ua/tekhnologii/okantonovokryilennyiy-mechtoy-106820 (accessed 08 May 2018). (Rus).

3. Available at: http://to-name.ru/biography/oleg-antonov.htm (accessed 12 April 2017). (Rus).
4. Baranov M.I. An anthology of the distinguished achievements in science and technique. Part 41: Composite materials: their classification, technologies of making, properties and application domains in modern technique. Electrical engineering \& electromechanics, 2017, no.6, pp. 3-13. doi: 10.20998/2074-272X.2017.6.01.

5. Available at: https://en.wikipedia.org/wiki/Antonov An-72 (accessed 25 October 2017).

6. Available at: https://militaryarms.ru/voennayatexnika/aviaciya/an-124-ruslan (accessed 22 May 2017). (Rus).

7. Available at: https://ruspekh.ru/events/item/ispytatelnyjpolet-samoljota-an-225-mriya (accessed 10 July 2017). (Rus).

8. Baranov M.I., Buriakovskyi S.G., Rudakov S.V. The tooling in Ukraine of model tests of objects of energy, aviation and space-rocket engineering on resistibility to action of pulsed current of artificial lightning. Electrical engineering \& electromechanics, 2018, no.4, pp. 45-53. doi: 10.20998/2074272X.2018.4.08.

9. Available at: http://www.stoletie.ru/sozidateli/legendarnyi aviakonstruktor 6

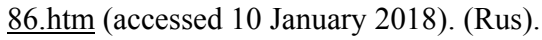

10. Bondar' O.I. O.K. Antonov - mnogogrannost' talanta [O.K. Antonov is many-sided nature of talent]. Kyiv, Aerohobby Publ., 2012. 192 p. (Rus).

11. Available

http://www.warheroes.ru/hero/hero.asp?id=21788 (accessed 12 September 2017). (Rus).

12. Available at: http://www.warheroes.ru/hero/hero.asp?id=18548 (accessed 28 November 2017). (Rus).

13. Available at: https://en.wikipedia.org/wiki/Antonov (accessed 23 July 2017).

Received 25.10.2018

M.I. Baranov, Doctor of Technical Science, Professor, Scientific-\&-Research Planning-\&-Design Institute «Molniya», National Technical University «Kharkiv Polytechnic Institute», 47, Shevchenko Str., Kharkiv, 61013, Ukraine, phone +380 57 7076841,

e-mail: baranovmi@kpi.kharkov.ua

How to cite this article:

Baranov M.I. An anthology of the distinguished achievements in science and technique. Part 49: Aircraft designer Oleg Antonov and his accomplishments in airplane design. Electrical engineering \& electromechanics, 2019, no.3, pp. 3-10. doi: 10.20998/2074-272X.2019.3.01. 